\title{
PENGEMBANGAN PENDIDIKAN KARAKTER DALAM PENDIDIKAN JASMANI DAN OLAHRAGAPADA PENDIDIKAN ANAK USIA DINI
}

\author{
Hariadi \\ Fakultas Ilmu Keolahragaan \\ Universitas Negeri Medan
}

\begin{abstract}
Character education is an efforts that is designed and implemented systematically to embedded the values of learner behaviour associated with the God, ourselves, human beings, the environment, and nationality embodied in thoughts, attitudes, feelings, speaking, and actions based on religious norms, laws, manners, culture, and customs. Physical Education and Sport (PENJASOR) is essentially a Education processes that utilizes physical activity (motion) to produced a holistic change in individual quality, like on physical, mental, and emotional. Physical education treated the children as a unified whole, total creature, rather than just think of it as someone who separated physical quality and mental. Through the Penjasor learning process is a medium that is considered very precise and powerful in Established of a system of values and character. That aka materialized when given stimulus as early as possible in accordance with the laws of child development.
\end{abstract}

Keywords: character education, physical education, sports, early children

\begin{abstract}
Abstrak: Pendidikan karakter merupakan upaya-upaya yang dirancang dan dilaksanakan secara sistematis untuk menanamkan nilai-nilai perilaku peserta didik yang berhubungan dengan Tuhan Yang Maha Esa, diri sendiri, sesama manusia, lingkungan, dan kebangsaan yang terwujud dalam pikiran, sikap, perasaan, perkataan, dan perbuatan berdasarkan norma-norma agama, hukum, tata krama, budaya, dan adat istiadat. Pendidikan Jasmani dan Olahraga (PENJASOR) pada hakikatnya adalah proses pendidikan yang memanfaatkan aktivitas fisik (gerak) untuk menghasilkan perubahan holistik dalam kualitas individu, baik dalam hal fisik, mental, serta emosional. Pendidikan jasmani memperlakukan anak sebagai sebuah kesatuan utuh, mahluk total, daripada hanya menganggapnya sebagai seseorang yang terpisah kualitas fisik dan mentalnya. Pembelajaran Penjasor merupakan media yang dipandang sangat tepat dan ampuh dalam pembentukan sistem nilai dan karakter. Pembentukan karakter aka terwujud bila diberikan rangsangan sedini mungkin sesuai dengan hukum perkembangan anak.
\end{abstract}

Kata kunci: pendidikan karakter, pendidikan jasmani, olahraga, usia dini

\section{PENDAHULUAN}

Permasalahan yang mendasar dalam dunia pendidikan di Indonesia adalah masalah kualitas, kuantitas, dan relevansi. Peningkatan kualitas pendidikan dewasa ini merupakan kebutuhan yang mendesak, mengingat kualitas pendidikan di Indonesia sudah jauh tertinggal dari negara tetangga, apalagi jika dibandingkan dengan negara maju (Puskur Diknas 2007). Di pihak lain, kegiatan pembangunan yang sedang dilaksanakan membutuhkan sumberdaya manusia yang berkualitas, berkarakter kuat, demokratis, dan tanggap terhadap masalah-masalah praktis yang harus segera diselesaikan. Sumber daya manusia yang demikian sangat dipengaruhi oleh kualitas pendidikan, termasuk pendidikan jasmani bagi pendidikan anak usia dini (penjas paud)

Usia dini merupakan periode awal yang paling penting dan mendasar dalam rentang pertumbuhan serta perkembangan kehidupan manusia. Pada masa ini ditandai oleh berbagai periode penting yang fundamen dalam kehidupan anak selanjutnya sampai periode akhir perkembangannya. Salah satu periode yang menjadi penciri masa usia dini adalah the Golden Ages atau periode keemasan. Banyak konsep dan fakta yang ditemukan memberikan penjelasan tentang periode keemasan pada masa usia dini. Pada masa ini semua potensi anak berkembang. 
Beberapa konsep yang disandingkan untuk masa anak usia dini adalah masa eksplorasi, masa identifikasi/imitasi, masa peka, masa bermain dan masa trozt alter 1 (masa membangkang tahap 1).

Konsep tersebut diperkuat oleh fakta yang ditemukan oleh ahli-ahli neurologi yang menyatakan bahwa pada saat lahir otak bayi mengandung 100 sampai 200 milyar neuron atau sel syaraf yang siap melakukan sambungan antar sel. Sekitar 50\% kapasitas kecerdasan manusia telah terjadi ketika usia 4 tahun, $80 \%$ telah terjadi ketika berusia 8 tahun, dan mencapai titik kulminasi $100 \%$ ketika anak berusia 8 sampai 18 tahun (Fidesrinur, 2010). Pertumbuhan fungsional sel-sel syaraf tersebut membutuhkan berbagai situasi pendidikan yang mendukung, baik dalam situasi pendidikan keluarga, masyarakat maupun sekolah yang didasari penanaman nilai dan karakter yang kauat. Para ahli pendidikan sepakat bahwa periode keemasan tersebut hanya berlangsung satu kali sepanjang rentang kehidupan manusia. Hal ini menunjukkan bahwa betapa meruginya suatu keluarga, masyarakat dan bangsa jika mengabaikan masa-masa penting yang berlangsung pada anak usia dini (Puskur Diknas 2007).

Sebagai komitmen dan keseriusan antar bangsa terhadap pendidikan anak usia dini telah dicapai berbagai momentum dan kesepakatan penting yang telah digalang secara internasional. Salah satunya adalah Deklarasi Dakkar yang diantaranya menyepakati bahwa perlunya upaya memperluas dan memperbaiki keseluruhan perawatan dan pendidikan anak usia dini, terutama bagi anak-anak yang sangat rawan dan kurang beruntung. Adapun komitmen antara bangsa secara internasional lainnya adalah kesepakatan antar negara yang tergabung dalam Perserikatan Bangsa-Bangsa yang menyepakati "Dunia yang layak bagi anak 2002" atau dikenal dengan "world fit for children 2002". Beberapa kesepakatan yang diperoleh adalah (1) mencanangkan kehidupan yang sehat, (2) memberikan pendidikan yang berkualitas, (3) memberikan perlindungan terhadap penganiayaan, eksploitasi dan kekerasan. Program PAUD diselenggarakan sebelum jenjang pendidikan dasar dan dapat diselenggarakan melalui jalur pendidikan formal, non formal dan informal. Walapun berbagai upaya secara konseptual maupun praktis telah diupayakan dalam membangun anak usia dini sesuai pasal 28 UU no 20 tahun 2003, namun masih banyak anak usia dini di Indonesia yang belum terlayani kebutuhannya pada bidang pendidikan (sensus BPS terbaru 2005 mencapai 26 juta).

Pada sisi lain, kelembagaan pendidikan anak usia dini yang ada baru dapat menampung sebesar 27\%. Angka Partisipasi Kasar (APK) tahun 2005 dan telah mencapai $60 \%$ tahun 2010. Hal ini diperburuk dengan masih rendahnya kualitas penyelenggaraan lembaga pendidikan anak usia dini yang dilihat dari aspek standar program yang diberikan, proses pembelajaran yang belum mengakomodasi kebutuhan anak (termasuk rangsangan dan kebutuhan akan gerak/olah raga yang samapai sekarang tidak masuk dalam kurikulum). Kualitas serta kualifikasi tenaga pendidik anak usia dini yang masih tergolong rendah (bahkan tidak ada pendidik khusus disediakan pemerintah untuk guru penjas usia dini). Dalam rangka membantu memenuhi kebutuhan anak usia dini pada bidang pendidikan (termasuk Penjasor), maka pemerintah berusaha menfasilitasi dengan dikembangkannya Kurikulum PAUD yang diharapkan dapat membantu memberikan pendidikan yang berkualitas pada anak usa dini.

Dengan rujukan kurikulum ini diharapkan dapat membantu lembaga pendidikan keluarga (informal), lembaga pendidikan masyarakat (nonformal) dan lembaga pendidikan anak usia dini formal dalam memperoleh akses konsep kurikulum yang memasukkan penjas anak usia dini. Oleh karena itu, uraian berikut semoga dapat memberikan gambaran bagi kita secara filofis dan teoritis untuk memahami konsep pendidikan karakter, pendidikan jasmanidan olah raga anak usia dini, dan pengembangan penjas dan olahraga sebagai salah satu media pembentukan karakter. 


\section{Pendidikan Karakter}

Tidak dapat disangkal bahwa hanya melalui pendidikan diharapakan terjadinya transformasi perubahan menuju insan yang maju, cerdas dan kompetitif. Dan sungguh diyakini bahwa dengan Sumber Daya Manusia yang berkarakter kuat insan maju, cerdas dan kompetitif dapat diraih. Oleh karenanya penyelenggaraan pendidikan karakter perlu menjadi perhatian sehingga visi dan cita-cita pendidikan nasional 2025 dapat diwujudkan. Adapun makna Insan cerdas Indonesia sesuai dengan visi Pendidikan Nasonal 2025 adalah cerdas spirutual, cerdas emosi dan sosial, cerdas intelektual, dan cerdas kinestetik. (Renstra Diknas 20102014).

Adapun makna insan cedas dan kompetitif tersebut adalah: Cerdas spiritual, beraktualisasi diri melalui olah hati/kalbu untuk menumbuhkan dan memperkuat keimanan, ketakwaan dan akhlak mulia, termasuk budi pekerti luhur dan kepribadian unggul. Cerdas emosional dan sosial, beraktualisasi diri melalui olah rasa untuk meningkatkan sensitivitas dan apresiativitas akan kehalusan dan keindahan seni dan budaya, serta kompetensi untuk mengekspresikannya; Beraktualisasi diri melalui interaksi sosial yang (a) membina dan memupuk hubungan timbal balik; (b) demokratis; (c) empatik dan simpatik; (d) menjunjung tinggi hak asasi manusia; (e) ceria dan percaya diri; (d) menghargai kebhinekaan dalam bermasyarakat dan bernegara; (e) berwawasan kebangsaan dengan kesadaran akan hak dan kewajiban warga negara.

Cerdas intelektual, Beraktualisasi diri melalui olah pikir untuk memperoleh kompetensi dan kemandirian dalam ilmu pengetahuan dan teknologi. Aktualisasi insan intelektual yang kritis, kreatif, inovatif dan imajinatif. Cerdas kinestetis, Beraktualisasi diri melalui olah raga untuk mewujudkan insan yang sehat, bugar, berdaya-tahan, sigap, terampil, dan trengginas. Aktualisasi insan adiraga.

Sementara Makna Insan Kompetitif Indonesia adalah Berkepribadian unggul dan gandrung akan keunggulan, Bersemangat juang tinggi, Mandiri, Pantang menyerah, Pembangun dan pembina jejaring, Bersahabat dengan perubahan, Inovatif dan menjadi agen perubahan, Produktif, Sadar mutu, Berorientasi global Pembelajaran sepanjang hayat, Menjadi rahmat bagi semesta alam (Renstra Diknas tahun 2010-2014). Berdasarkan uraian di atas bahawa untuk melahirkan insan cerdas kompetitif yang memiliki kepribadian, tidak lepas dengan bagaimana kita membentuk karakter SDM.

Pembentukan karakter SDM menjadi vital dan tidak ada pilihan lagi untuk mewujudkan Indonesia baru, yaitu Indonesia yang dapat menghadapi tantangan regional dan global (Muchlas dalam Sairin, 2001: 211). Tantangan regional dan global yang dimaksud adalah bagaimana generasi muda kita tidak sekedar memiliki kemampuan kognitif saja, tetapi aspek afektif dan moralitas juga tersentuh. Untuk itu, pendidikan karakter diperlukan untuk mencapai manusia yang memiliki integritas nilai-nilai moral sehingga anak menjadi hormat sesama, jujur dan peduli dengan lingkungan.

Lickona (1992) menjelaskan beberapa alasan perlunya pendidikan karakter, di antaranya: (1) Banyaknya generasi muda saling melukai karena lemahnya kesadaran pada nilai-nilai moral; (2) Memberikan nilai-nilai moral pada generasi muda merupakan salah satu fungsi peradaban yang paling utama; (3) Peran sekolah sebagai pendidik karakter menjadi semakin penting ketika banyak anakanak memperoleh sedikit pengajaran moral dari orangtua, masyarakat, atau lembaga keagamaan; (4) masih adanya nilai-nilai moral yang secara universal masih diterima seperti perhatian, kepercayaan, rasa hormat, dan tanggungjawab; (5) Demokrasi memiliki kebutuhan khusus untuk pendidikan moral karena demokrasi merupakan peraturan dari, untuk dan oleh masyarakat; (6) Tidak ada sesuatu sebagai pendidikan bebas nilai; (7) Komitmen pada pendidikan karakter penting manakala kita mau dan terus menjadi guru yang baik. Ketujuh pendidikan karakter yang efektif ini membuat sekolah lebih beradab, peduli pada masyarakat, dan mengacu pada performansi akademik yang meningkat. 
Alasan-alasan di atas menunjukkan bahwa pendidikan karakter sangat perlu ditanamkan sedini mungkin untuk mengantisipasi persoalan di masa depan yang semakin kompleks seperti semakin rendahnya pehatian dan kepedulian anak terhadap lingkungan sekitar, tidak memiliki tanggungjawab, rendahnya kepercayaan diri, dan lainlain. Untuk mengetahui lebih jauh tentang apa yang dimaksud dengan pendidikan karakter,

Lickona dalam Elkind dan Sweet (2004) menggagas pandangan bahwa pendidikan karakter adalah upaya terencana untuk membantu orang untuk memahami, peduli, dan bertindak atas nilai-nilai etika/ moral. Pendidikan karakter ini mengajarkan kebiasaan berpikir dan berbuat yang membantu orang hidup dan bekerja bersamasama sebagai keluarga, teman, tetangga, masyarakat, dan bangsa.

Menurut Elkind \& Sweet (2004), pendidikan karakter dimaknai sebagai berikut:

Character education is the deliberate effort to help people understand, care about, and act upon core ethical values. When we think about the kind of character we want for our children, it is clear that we want them to be able to judge what is right, care deeply about what is right, and then do what they believe to be right, even in the face of pressure from without and temptation from within.

Hal ini berarti bahwa pendidikan karakter bukan sekedar mengajarkan mana yang benar dan mana yang salah, lebih dari itu, pendidikan karakter menanamkan kebiasaan (habituation) tentang hal mana yang baik sehingga peserta didik menjadi paham (kognitif) tentang mana yang benar dan salah, mampu merasakan (afektif) nilai yang baik dan biasa melakukannya (psikomotor). Dengan kata lain, pendidikan karakter yang baik harus melibatkan bukan saja aspek "pengetahuan yang baik (moral knowing), akan tetetapi juga "merasakan dengan baik atau loving good (moral feeling), dan perilaku yang baik (moral action). Pendidikan karakter menekankan pada habit atau kebiasaan yang dipraktikkan dan dilakukan.

Berdasarkan pembahasan di atas dapat ditegaskan bahwa pendidikan karakter merupakan upaya-upaya yang dirancang dan dilaksanakan secara sistematis untuk menanamkan nilai-nilai perilaku peserta didik yang berhubungan dengan Tuhan Yang Maha Esa, diri sendiri, sesama manusia, lingkungan, dan kebangsaan yang terwujud dalam pikiran, sikap, perasaan, perkataan, dan perbuatan berdasarkan norma-norma agama, hukum, tata krama, budaya, dan adat istiadat.

Dengan demikian pengembangan nilai-nilai etika inti mensyiratkan keyakinan tentang apa saja sifat karakter dan bagaimana caranya menjadi pribadi yang benar dan baik secara moral (Alim Sumarno 2011). Etika adalah aturan dasar yang digunakan untuk memperolah seluruh nilai-nilai yang lain. Nilai etika inti menurut Thomas Lickona (dalam Alim Sumarno 2011) adalah nilai yang menjunjung tinggi hak asasi manusia dan memperkokoh martabat manusia (Alim Sumarno, 2011).

Secara universal nilai etika inti meliputi: kesalehan (piety), keterpecayaan (trustworthines), hormat (respect), tanggung jawab (resposibility), keadilan (fairnes), kepedulian (caring), dan kewarganegaraan (citizenship). Kesalehan berarti percaya kepada Tuhan (yang diyakininya) dan memiliki komitmen untuk melaksanakan ajarannya dan tuntunanya yakni; beribadah, menghormati sesama, dan melestarikan serta menjaga lingkungan sebagai habitat hidup. Keterpecayaan berarti meliputi sifat seperti integritas, keteguhan hati, kejujuran, keberanian, ketulusan hati, terus terang, andal,menepati janji dan loyalitas. Hormat memiliki makna menghargai semua orang dan mahluk, menghargai maratabat, privasi dan kebebasan ranag lain, santun dan toleran terhadap perbedaan. Tanggung jawab berarti kesadaran untuk melaksanakan hak dan kewajiban secara seimbang, mengetahui apa yang diakukan dan yang tidakk diakukan) serta akibat-akibat yang ditimbukannya. Dengan tanggung jawab dapat memanggil kita untuk memenuhi komitmen. Seseorang dapat 
dinalai bertanggung jawab jika ia melakukan pekerjaan bagi kelompoknya.

Dalam kehidupan ada tiga kategori tanggung jawab yakni tanggung jawab yang berpusat pada norma atau tanggung jawab kolektif (bertindak sesuai dengan norma kelompok), tanggung jawab empatik (personal) yang digerakkan oleh penderitaan lain, dan tanggung jawab universal sosial. Adil berarti bersifat atau bersikap tidak memihak dan konsisten terhadap orang lain, bersedia mendengar dan terbuka terhadap pandangan yang berbeda, mengikuti prosedur yang adil terhadap oarang lain dalam situasi yang ada. Kepedulian adalah esensi dari nilai etika. Peduli terhadap nilai, cinta, kehormatan, kota negara dan dunia. Peduli akan kebaikan, rasa kasih, berjasa dan berbuat baik, mementingkan orang lain, dermawan, murah hati dan kebersamaan adalah esensi dari etika. Kewarganegaraan yang baik berarti memiliki rasa hormat terhadap hukum dan adat istiadat suatu negara, menghargai benrdera dan segala simbol, gotong royong membantu komunitas, bermain sesuai aturan masyarakat dan menghormati figur pemimpin dan representasinya (Alim Sumarno, 2011).

\section{Pendidikan Jasmani Anak Usia Dini}

Hakikat Pendidikan Jasmani dan Olah raga (penjasor) adalah proses pendidikan yang memanfaatkan aktivitas fisik untuk menghasilkan perubahan holistik dalam kua litas individu, baik dalam hal fisik, mental, serta emosional. Pendidikan jasmani memperlakukan anak sebagai kesatuan utuh, mahluk total, daripada hanya menganggapnya sebagai seseorang yang terpisah kualitas fisik dan mentalnya (Mahendra, 2007). Dengan demikian kenyataannya, penjasor adalah suatu bidang kajian yang sungguh luas. Titik perhatiannya adalah peningkatan gerak manusia. Lebih khusus lagi, penjasor berkaitan dengan hubungan antara gerak manusia dan wilayah pendidikan lainnya: hubungan dari perkembangan tubuh-fisik dengan pikiran dan jiwanya. Fokusnya pada pengaruh perkembangan fisik terhadap wilayah pertumbuhan dan perkembangan aspek lain dari manusia itulah yang menjadikannya unik. Tidak ada bidang tunggal lainnya seperti penjasor yang berkepentingan dengan perkembangan total manusia.

Penjasor menyebabkan perbaikan dalam 'pikiran dan tubuh' yang mempengaruhi seluruh aspek kehidupan harian seseorang. Pendekatan holistik tubuh-jiwa ini termasuk pula penekanan pada ketiga domain kependidikan: psikomotor, kognitif, dan afektif. Seperti ungkapan Robert Gensemer, penjasor diistilahkan sebagai proses menciptakan "tubuh yang baik bagi tempat pikiran atau jiwa." Artinya, dalam tubuh yang baik 'diharapkan' pula terdapat jiwa yang sehat, sejalan dengan pepatah Romawi Kuno: "Men sana in corporesano".

Berdasarkan hal tersebut di atas, penjasor sebagai bagian yang tidak terpisahkan dari pendidikan secara keseluruhan memiliki peran sebagai pondasi bagi tumbuh kembang anak (termasuk anak usia dini). Dengan demikian, pendidikan jasmani dapat mengembangkan seluruh potensi yang dimiliki anak (usia dini) yakni aspek organis, perseptual, kognitif, sosial dan emosional.

Menurut Suherman (2007), kekhasan penjasor dapat digunakan sebagai landasan yang kokoh bagi anak (usia dini), diperlukan agar anak memiliki kondisi jasmani, intelektual dan mental spiritual yang baik memadahi untuk berkembang lebih lanjut sesuai dengan potensi masing-masing. Untuk meningkatkan peran penjasor sebagai pondasi bagi tumbuh kembang anak perlu dilakukan berbagai upaya, diantaranya, melaksanakan pembelajaran yang menarik, menyenangkan (terutama bagi anak usia dini) dan menantang. Yang paling penting adalah Menumbuhkan rasa aman dan nyaman adalah dasar yang utama dalam membentuk karakter anak,yang kemudian dapat menumbuhkan rasa "berarti", "berharga" atau "bernilai" pada anak (Nana Prasetyo, 2011). Selain itu, meningkatkan pendidikan guru penjasor, memenuhi sarana dan prasarana di sekolah agar memadahi untuk proses penjasor, melaksanakan pembaharuan kurikulum agar sesuai kebutuhan peserta didik dan kemampuan sekolah serta meningkatkan kualitas lembaga maupun tenaga pendidikan. 


\section{Kondisi Penjasor Saat Ini}

Penjasor merupakan media untuk mendorong pertumbuhan fisik, perkembangan psikis, keterampilan motorik, pengetahuan dan penalaran, penghayatan nilai-nilai (sikapmental-emosional sportivitas-spiritual-sosial), serta pembiasaan pola hidup sehat yang bermuara untuk merangsang pertumbuhan dan perkembangan kualitas fisik dan psikis yang seimbang. Namun fenomena di lapangan menyatakan bahwa penjasor di lembaga-lembaga pendidikan belum dapat memposisikan dirinya pada tempat yang terhormat, bahkan masih sering dilecehkan; misalnya pada masa-masa menjelang ujian akhir suatu jenjang pendidikan, maka penjasor dihapuskan dengan alasan agar para siswa dalam belajarnya untuk menghadapi ujian akhir "tidak terganggu" (Giriwijoyo, 2007).

Aip Syarifuddin (2002) mengungkapkan bahwa, kualitas guru penjasor di sekolahsekolah pada umumnya kurang memadai. Mereka kurang mampu melaksanakan tugasnya secara profesional. Salah satu masalah utama dalam pengajaran penjasor di Indonesia adalah belum efektifnya pelaksanaan pengajaran penjasor di sekolah-sekolah. Kondisi ini disebabkan oleh beberapa faktor di antaranya adalah terbatasnya kemampuan guru dan terbatasnya sumber-sumber yang digunakan untuk mendukung proses pengajaran penjasor. Guru belum berhasil melaksanakan tanggung jawabnya untuk mendidik siswanya secara sistematik melalui kegiatan penjasor, untuk mengembangkan kemampuan dan ketrampilan siswa secara menyeluruh, baik dalam segi fisik, mental, intelektual maupun sosial dan emosionalnya.

Di sisi lain, di neagara kita masih banyak kalangan atau lembaga tidak memahami arti penting Penjasor. Hal tersebut bisa diketahui bahwa ada guru yang tidak punya latar belakang penjasor tiba-tiba saja memberikan pelajaran itu di sekolah. Penjasor di sekolah dasar seharusnya hanya mengenalkan gerakan dasar, seperti berlari, berjalan, melompat, dan melempar. Namun, banyak sekolah yang sudah mengajak siswa melakukan permainan cabang olahraga) dalam memberikan penjasor, apa lagi ini diberikan kepada anak usia dini (TK dan SD kelas rendah) yang memakai fasilitas cabang olahraga standar orang dewasa. Keadaan ini membahayakan bagi keselamatan dan perkembangan anak.

Selain itu, menurut Poerwati (2007), jam pelajaran untuk penjasor di sekolah, serta proses belajar dan mengajar yang masih sistem konvensional tradisional, masih jauh dari mencukupi untuk membentuk siswa yang bugar dan memiliki produktivitas belajar. Karena, rata-rata jam pelajaran di sekolah tingkat dasar hanya 80 menit perminggu, sedangkan untuk $\mathrm{TK} / \mathrm{KB}$ belum ada jam khusus dengan demikian juga belum tersedia guru khusus penjas. Sehingga, penambahan jam pelajaran penjasor dari rata-rata 80 menit perminggu ke angka ideal 180 menit perminggu memerlukan kemauan dari pihak pemerintah, terutama Departemen Pendidikan Nasional (Depdiknas).

Penjasor adalah bagian integral dalam proses pendidikan, tetapi ironisnya, model pendidikan ini dari dulu sampai sekarang tetap termarginalkan. Padahal, salah satu fondasi instrumen pembangunan bangsa adalah dengan kebugaran peserta didik yang harus dimiliki. Jadi kita tidak boleh berharap insan indonesia cerdas dan kompetetitif dapat diwujudkan melalui proses pendidikan yang berkarakter kuat yang mana konten dan proses sangat syarat dalam penjas dan olahraga. Namun dalam sistem pendidikan kita, hal ini kurang mendapat tempat yang selayaknya.

Terdapat fenomena yang cukup "menyedihkan" terkait mata pelajaran penjasor yang di sadur oleh (Muhlas 2008) ia mengutip dari berbagai sumber antara laian: 1) Tingkat Kesegaran Jasmani anak/remaja indonesia hasilnya rata-rata kategori kurang. Dengan rincian; 37,40\% Kurang Sekali, 43,90\% Kurang, $13,55 \%$ Sedang, 4,07\% Baik; dan 1,08\% Baik Sekali (SDI 2006): 2) Perilaku menyimpang dari anak dan remaja indonesia juga makin tinggi dan bervariasi hasil riset WHO melaporkan bahwa $44 \%$ remaja usia 14-18 th telah melakukan hubungan badan sebelum nikah (Kompas, 27 Nov 2007, survei Jkt, Sby, Bdg, Mdn) ; 3) Pola hidup kurang gerak (sedentary lifestyle) 
dialami sekitar $2 / 3$ anak terutama di negaranegara sedang berkembang (WHO, 2002) ; 4) Pemahaman internal sekolah bahwa mapel penjasor adalah membosankan, menghambur waktu dan mengganggu perkembangan intelektual anak (Suherman, 2004)

Melihat kondisi pelaksanaan penjasor yang begitu menyedihkan di sekolah rasanya menjadi terlalu berlebihan kalau kita berharap menjadi bangsa yang besar di bidang olah raga. Penjasor tak ubahnya benih dan kita tidak akan pernah menuai apa pun kalau kita tidak pernah menanamnya. Oleh karena itu bibit yang kita tanam dan kita pelihara dengan baik dan akan memberikan karakter masa depan bangsa adalah melalui penjasor pada anak usia dini. Karena "pendidikan tidak akan lengkap dan sempurna tanpa adanya pelajaran olah raga karena gerakan manusia adalah dasar dari pada cara belajar mengenal dunia sekelilingnya dan dirinya sendiri”. Olah raga untuk pendidikan Usia Dini atau Taman Kanak pada umumnya dilaksanakan pada bentuk permainan.

\section{METODOLOGI PENELITIAN}

Adapun tujuan secara umum membina pertumbuhan fisik yang harmonis, meningkatkan stabilitas, psikososial, serta membantu mengembangkan kemauan dan kepribadiannya (Gunawan, 2011).

HASIL DAN PEMBAHASAN

Pengembangan Pendidkan Karakter dalam Penjasorpada Anak Usia Dini
Pendidikan karakter pada dasarnya dapat diintegrasikan dalam pembelajaran pada setiap mata pelajaran. Materi pembelajaran yang berkaitan dengan norma atau nilai-nilai pada setiap mata pelajaran perlu dikembangkan, dieksplisitkan, dikaitkan dengan konteks kehidupan sehari-hari. Dengan demikian, pembelajaran nilai-nilai karakter tidak hanya pada tataran kognitif, tetetapi menyentuh pada internalisasi, dan pengamalan nyata dalam kehidupan peserta didik sehari-hari di masyarakat. Penanaman karakter tersebut jauh lebih berbeakas bila dimuai dari anak masih kecil yang kita kenal pada anak usia dini, sebagai mana yang telah kita uraikan ditas

Berdasarkan grand design yang dikembangkan Kemendiknas (2010), secara psikologis dan sosial kultural pembentukan karakter dalam diri individu merupakan fungsi dari seluruh potensi individu manusia (kognitif, afektif, konatif, dan psikomotorik) dalam konteks interaksi sosial kultural (dalam keluarga, sekolah, dan masyarakat) dan berlangsung sepanjang hayat. Konfigurasi karakter dalam konteks totalitas proses psikologis dan sosial-kultural tersebut dapat dikelompokkan dalam: Olah Hati (Spiritual and emotional development), Olah Pikir (intellectual development), Olah Raga dan Kinestetik (Physical and kinestetic development), dan Olah Rasa dan Karsa (Affective and Creativity development) yang secara diagramatik dapat digambarkan sebagai berikut:

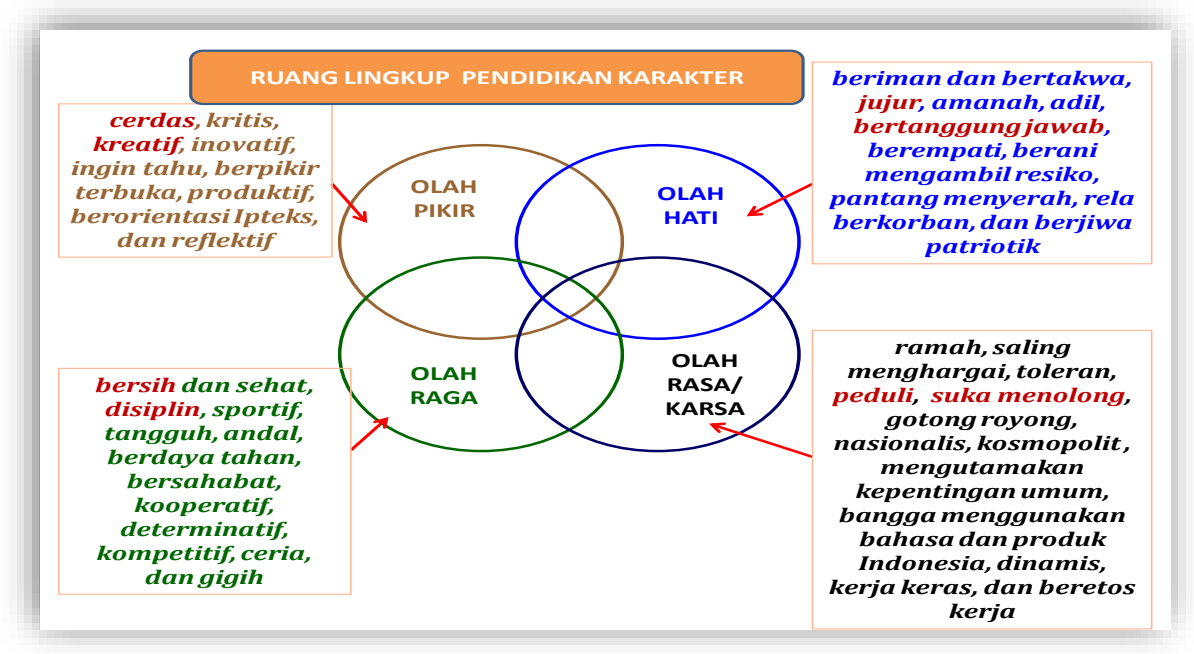




\section{Gambar 1. Ruang Lingkup Pendidikan Karakter (Kemdiknas, 2011)}

Karakter olahraga dapat diperoleh dengan pendidikan jasmani yang diajarkan baik di sekolah maupun di luar sekolah. Dari diagram di atas secara jelas dapat dilihat pentingnya pendidikan jasmani dalam pendidikan karakter. Pendidikan jasmani dalam proses pendidikan sebaiknya mengembangkan karakter, sistem nilai dan karakter menurut David Shield dan Brenda Bredemeir adalah empat kebajikan dimana seseorang yang mempunyai karakter bagus akan mampu menampilkan compassion (rasa belas kasih), fairness (keadilan), sportsmanship (ketangkasan) dan integritas. Dengan adanya rasa belas kasih, atlit dapat diberi semangat untuk melihat lawan sebagai kawan dalam permainan, sama-sama bernilai, sama-sama patut menerima penghargaan. Keadilan melibatkan tidak keberpihakan, sama-sama tanggung jawab. Ketangkasan dalam olahraga membutuhkan usaha secara intens menuju sukses. Integritas memungkinkan seseorang untuk menerima kesalahan orang lain, sebagai con-toh meskipun tindakannya negatif peneriman-nya oleh wasit, teman satu tim ataupun fans namun tetap fokus terhadap tujuan atau tim.

Pendidikan karakter tidak hanya memperkuat akal, melainkan memelihara hati, sehingga bangsa ini memiliki pola pikir, pola sikap dan pola tindakan yang mulia atau luhur sesuai dengan nilai-nilai universal, karena karakter yang baik tidak terbentuk secara otomatis, melainkan bertahap, perlahan-lahan, melalui pembiasaan dan keteladanan. Dalam pendidikan karakter, tidak akan terlepas dari tiga hal yang oleh Thomas Lickona disebut sebagai moral knowing, moral feeling dan moral action. Keterkaitan di antara ketiga hal tersebut dapat dilihat pada Gambar 1 berikut ini.

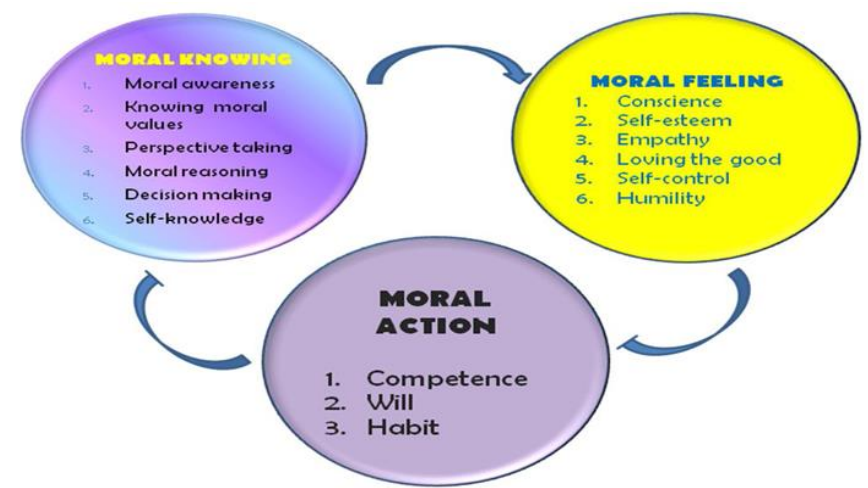

\section{Gambar 2. Keterkaitan antara Moral Knowing,} Moral Feelingdan Moral Action (JPNF, 2011)

Pendidikan karakter merupakan hasil dari sebuah proses panjang yang berjalan secara tertahap, serta dimulai sejak usia dini. Hal ini menjadi sangat penting, mengingat usia dini merupakan dasar pembentukan perilaku. Pada usia dini segenap potensi anak berkembang. Dan hal ini tidak terlepas dari perkembangan luar biasa dari otak, sehingga usia dini merupakan golden period dalam rentang kehidupan manusia. Otak merupakan pusat belajar dan proses belajar berlangsung di wilayah sadar bagian luar atau bagian otak yang berwarna kelabu. Wilayah inilah yang disebut sebagai cerebral cortex. Proses belajar awal memerlukan banyak darah dan oksigen. Akan tetetapi, lama kelamaan, apabila sesuatu hal diulangi dan menjadi kebiasaan, maka proses ini akan berpindah ke wilayah otak bawah sadar dan bersifat otomatis. Wilayah ini disebut sebagai basal ganglia.

Semakin sering melakukan sesuatu, semakin otomatis dan tidak disadari hal tersebut, sehingga menjadi suatu kebiasaan dan lama kelamaan diperkuat. Jadi, ketika pertama kali seseorang melakukan sesuatu, maka jalur "neurolog" belum terbentuk, dan akan terbentuk ketika perilaku tertentu 
diulangi. Sambungan-sambungan baru (neurotransmitter) akan terbentuk dan semakin lama menjadi semakin efisien, bahkan menjadi semakin tebal sehingga akan memproses rangsangan dengan lebih cepat. Hal ini akan menjadi bagian dari struktur fisiologi sebuah kebiasaan atau bahkan karakter.

Otak memang memiliki kemampuan yang menakjubkan untuk menerima pikiran atau perilaku yang berulang dan menyambungkannya ke dalam pola atau kebiasaan yang bersifat otomatis dan berada di alam bawah sadar. Proses ini dimulai dengan pemilihan sadar yang pertama, dan melalui pengulangan, kebiasaan itu mulai berpindah ke bagian belakang pikiran bawah sadar yang tenang. Apabila seorang anak senantiasa mendapatkan dukungan positif dalam mengembangkan karakter mulia, maka akan mengembangkan pikiran positif atau yang bersifat konstruktif, sehingga jalur ini akan semakin tebal dan terbentuk secara otomatis dalam alam bawah sadar, demikian pula sebaliknya. Ketika seseorang mengembangkan pikiran yang bersifat destruktif, maka ini pulalah yang akan menjadi jalur yang tebal dan bebas hambatan. Hal ini dapat dipahami ketika seseorang mengembangkan perilaku respons terhadap kesulitan dengan baik, akan menjadi kebiasaan baik yang menetap, demikian pula sebaliknya. Kebiasaan ini akan semakin kuat ketika sudah berada dalam otak bawah sadar. Oleh karena itu, kebiasaan yang buruk dapat diubah secara berulang dengan mengembangkan kebiasaan baik (Stoltz 2000).

Berbagai peneliti, antara lain Campbel \& Bond (1982 dalam Papalia, E.D., dkk, 2008 yang dikutip Puspita, Fardhana 2011) menyatakan bahwa pengalaman masa kecil menjadi faktor perkembangan moral dan perilaku remaja. Dalam hal ini, untuk memahami keberhasilan dan problem-problem perkembangan pada usia remaja dapat dilacak dari proses-proses perkembangan yang terjadi sejak usia dini. Dengan demikian, berbagai pengetahuan dan pengalaman anak pada masa kecil memiliki pengaruh dalam perkembangan perilaku dalam usia-usia berikutnya.

Perkembangan perilaku akan menuju pada kualitas yang handal apabila dilakukan sejak usia dini. Pada usia dini, mendidik karakter seperti menggoreskan tinta emas yang akan meninggalkan jejak bagi anak pada usia selanjutnya. Karakter yang dibangun sejak usia dini sangat menentukan kualitas sumber daya manusia selanjutnya, dan karakter sebuah individu, masyarakat dan bangsa akan sangat tergantung pada kualitas sumber daya manusia.

Freud (Papalia 2008 dalam Puspita, Fardhana 2011) menyatakan bahwa kegagalan penanaman kepribadian yang baik di usia dini akan membentuk pribadi yang bermasalah di masa dewasanya kelak. Kesuksesan orang tua membimbing anaknya dalam mengatasi konflik kepribadian di usia dini sangat menentukan kesuksesan anak dalam kehidupan sosial di masa dewasanya kelak. Oleh karena itu melalui pembelajaran Penjasor dari usia dini akan dapat menanamkan nilai yang akan menentukan prilaku dan karakter anak pada fase perkembangan selanjutnya. Hal tersebut dapat kita lihat pada gambar berikut: 


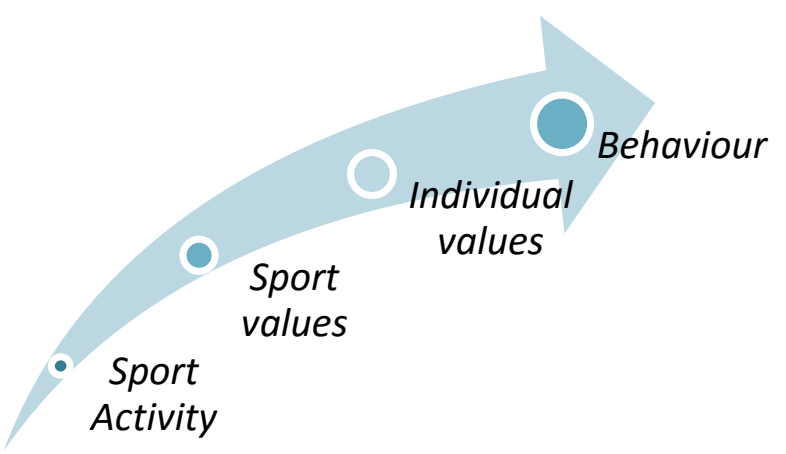

\section{Bagan 1. Model Konseptual Hubungan Olahraga-Nilai}

Kita telah menyadari bahwa pendidikan jasmani adalah laboratorium bagi pengalaman manusia, oleh sebab itu guru pendidikan jasmani harus mengajarkan etika dan nilai dalam proses belajar mengajar, yang mengarah pada kesempatan untuk membentuk karakter anak. Karakter anak didik yang dimaksud tentunya tidak lepas dari karakter bangsa Indonesia serta kepribadian utuh anak, selain harus dilakukan oleh setiap orangtua dalam keluarga, juga dapat diupayakan melainkan pendidikan nilai di sekolah.

Salah satu hal yang dapat diangkat sebagai sarana adalah tindakan nyata dan penghayatan hidup dari para pendidik atau sikap keteladanan mereka dalam menghayati nilai-nilai yang mereka ajarkan akan dapat secara instingtif mengimbas dan efektif berpengaruh pada peserta didik. Sebagai contoh, kalau guru sendiri memberi kesaksikan hidup sebagai pribadi yang selalu berdisiplin, maka kalau ia mengajarkan sikap dan nilai disiplin pada peserta didiknya, ia akan lebih disegani. Semua pendidik di sekolah, terutama para guru pendidikan jasmani perlu jeli melihat peluang-peluang yang ada, baik secara kurikuler maupun non/ekstra kurikuler, untuk menyadarkan pentingnya sikap dan perilaku positif dalam hidup bersama dengan orang lain, baik dalam keluarga, sekolah, maupun dalam masyarakat. Misalnya sebelum pelajaran dimulai, guru menegaskan bila anak tidak mengikuti pelajaran karena membolos, maka nilai pelajaran akan dikurangi.

Tujuan gerakan ollimpiade adalah menempatkan olahraga dimana saja sebagai wahana pembentukan manusia secara utuh yang harmonis dalam usaha membangun suatu masyarakat yang damai dengan saling menghormati. Mealui penerapan sistem nilai olahraga dan keteladanan yang ditampilkan guru (penjasor PAUD) diharapakan nilai luhur olahraga yang dicanangkan gerakan olimpade melalui olypism adalah keunggulan, persahabatan dan toleransi.

Keunggulan: bukan hanya olahragawan saja tetetapi untuk setiap orang, bukan hanya di lapangan dalam olahraga saja tetetapi dalam kehidupan dan berperilaku. Keunggulan dicapai melalui pembentukan badan yang kuat, pikiran dan perasaan yang jernih dan kemauan yang kuat. Persahabatan: Hubungan dalam kebersamaan antar sesama manusia, dibangun melalui kedamaian, solidaritas, kegembiraan dan selalu berpikir optimis. Penjasor sangat berperan. Toleransi/ saling menghormati: menghormati diri sendiri, orang lain, peraturan dan juga menghormati lingkungan. Hal demikian dalah perilaku fair play yang harus dimiliki setiap orang (khususnya olahragawan) dan termasuk menghindari halhal seperti doping.

Dalam banyak teori memberikan pendapat bahwa bagi anak usia dini sesuai dengan hukum perkembangan, bermain adalah media yang paling tepat dalam membentuk pengetahuan, nilai dan sikap bagai anaka usia dini

\section{Perkembangan Kosep Bermain Bagi Anak Usia Dini}

Walaupun para ilmuwan sulit untuk mengetahui kapan pendidikan anak usia dini 
dilaksanakan untuk pertama kali, namun diperkirakan sejak para ahli filsafat seperti Plato (427-374 B.C) dan Aristoteles (394-332 B.C) pendidikan ini telah dilaksanakan (Seefeldt dan Barbour, 1994:2).

Plato mengemukakan bahwa waktu yang paling tepat untuk pendidikan anak adalah sebelum usia 6 tahun. Menurut Comenius, pendidikan anak itu berlangsung sejalan dengan bermain karena bermain adalah realisasi dari pengembangan diri dalam kehidupan anak. Selanjutnya Johan Pastalozi (17461827) berpendapat bahwa pendidikan dimulai dari rumah, melalui berbagai kegiatan yang dilakukan anak pada waktu bermain dan berbagai pengalaman indera yang dialaminya.

Adapun pendapat yang menyatakan, bahwa pendidikan baru bisa dimulai setelah usia sekolah dasar, yaitu usia tujuh tahun, ternyata tidaklah benar. Hasil penelitian di bidang neurologi yang dilakukan Benyamin S. Bloom, seorang ahli pendidikan memperlihatkan, bahwa pertumbuhan sel jaringan otak pada anak usia 0-4 tahun mencapai 50\%, hingga usia 8 tahun mencapai $80 \%$. Artinya apabila pada usia tersebut otak anak tidak mendapatkan rangsangan yang optimal maka perkembangan otak anak tidak akan berkembang secara maksimal.

Semakin dini penanganan dan bentukbentuk rangsangan yang dilakukan orang tua/ pendidik terhadap anaknya maka hasilnya akan semakin baik. Sebaliknya, semakin lama (lambat) anak mendapatkan penanganan dan bentuk-bentuk rangsangan yang baik, maka semakin buruk hasilnya.

Plato adalah filsuf pertama yang memandang arti penting bermain bagi seorang anak. Plato melihat pentingnya nilai praktis yang ada dalam permainan. Misalnya pelajaran Aritmatika untuk soal pembagian akan mudah diterima oleh anak-anak dengan cara membagikan apel kepada mereka.

Sejarah perkembangan teori bermain juga berdampak positif terhadap reformasi pendidikan pada zaman realisme atau zaman baru. Zaman realisme abad 17 dipelopori oleh Johan Amos Comenius (1592-1670). Comenius mempelajari teologi dan menjadi pendeta serta memimpin sekolah di Fulneck.
Dia menulis buku tentang informatorium. Buku tersebut berisi tentang cara bagaimana orang tua mendidik anaknya menjadi seorang Kristen Protestan yang baik. Menurutnya seorang ibu adalah seorang pendidik di rumah, ibu harus mengajarkan dengan mengoptimalkan fungsi panca indera melalui peragaan dan mengurangi verbalisme.

Pada abad 18 atau zaman rasionalisme merupakan zaman perubahan yang hebat. Hal ini karena untuk memperoleh ilmu pengetahuan harus yang hebat. Dalam hal ini, untuk memperoleh ilmu pengetahuan harus dilakukan melalui percobaan, pengamatan dan pengalaman. Dalam konteks belajar sekarang ini, maka konsep belajar di atas hampir setara dengan konsep learning to know, learning to do, learning to be dan learning to live together.

John Lock (1932-1704) adalah seorang pedagogik. Lock menjelaskan kosep home Schooling. Anak usia dini harus dididik dan diajarkan tentang pendidikan jasmani, pendidikan scholastik, pendidikan moral, pendidikan agama melalui permainan. Pemikiran Locke dianjurkan oleh Jean Jacques Rousseau (1712-1778). Ia mengajarkan pendidikan rohani, moral, jasmani, berenang, pemahaman jender, melatih indera anak, kebebasan bermain, pengamatan, pengalaman, bahasa asing, menyanyi, menggambar pada anak usia dini melalui pengenalan alam sekitar dimana anak berada.

Henrich Pestaloozi (1746-1827) menjelaskan konsep bermain dengan praktik langsung sehingga anak mempunyai pengalaman dan latihan. Rumah adalah tempat anak bermain. Konsep bermain bagi anak usia dini memberi peluang tentang berhitung, menulis, bercakap-cakap, gerak badan, berjalan-jalan dengan bermain. Pestalozzi menjelaskan bahwa melalui bermain maka anak usia dini secara alamiah akan berusaha mengembangkan kemampuankemampuan dasarnya untuk belajar. Friedrich Froebel (1782- 1852) menjelaskan bahwa konsep bermain merupakan proses belajar bagi anak usia dini. Anak diajak bekerja di kebun, bermain dengan pimpinan, bernyanyi, pekerjaan tangan atau keterampilan, 
bersosialisasi, berfantasi, adalah merupakan proses belajar sambil bekerja. Konsep belajar seraya bermain ini sampai saat ini masih menjadi trend untuk pendidikan anak usia dini.

Abad 19 terdapat Spencer, Lazarus, G. Stanley H., Hal Groos. Dll. Teori-teori tentang bermain dapat dikelompokan dalam 2 bagian, yaitu: (1) bermain yang didasarkan pada teori surplus energi dan teori rekreasi, (2) teori rekapitulasi dan praktis. Herbert Spencer (kakek moyang Lady Diana) dari Inggris dalam bukunya Principles of Psychology berpendapat bahwa kegiatan bermain seperti berlari, berlompat, berguling terjadi akibat anak kelebihan energi.

Sebagai contoh, Saila, umur 9 bulan, begitu ia terjaga dari tidur maka ia langsung tertawa dan merangkak lalu berpegangan kedinding tangga dan meraih benda atau mainan apa saja yang menarik hatinya kemudian memainkannya lewat tangan, atau mulutnya sampai bosan kemudian beralih ke benda lain, seperti kertas dan plastik atau mainan lainnya untuk dimainkannya sampai capek dan tidur. Begitulah anak bermain dan ia belajar dari apa yang ia lihat, dengar, cium dan pegang dalam kehidupannya, seolah tanpa lelah, karena ia memang kelebihan energi dan merasa puas bereksplorasi dengan menyenangkan. Bila ia diganggu, dirampas apa yang ia pegang atau apa yang ia mainkan, maka ia akan menangis, kecuali diberikan benda pengganti yang sama-sama menarik untuk dirinya.

Moritz Lazarus dengan teori rekreasi menjelaskan, bahwa tujuan bermain adalah untuk memulihkan energi yang sudah terkuras saat bergerak atau melakukan sesuatu. Melakukan sesuatu atau bekerja dapat menyebabkan berkurangnya tenaga. Tenaga ini dapat dipulihkan kembali dengan cara tidur atau melibatkan dalam kegiatan yang sangat berbeda dengan bekerja.

Karl Groos, seorang filsuf menguraikan bahwa bermain berfungsi untuk memperkuat insting yang diperlukan untuk kelangsungan hidup anak di masa yang akan datang. Ia mendasarkan teorinya itu pada prinsip seleksi alamiah yang dijelaskan oleh Charles Darwin. Fungsi bermain mempunyai manfaat secara biologis untuk mempertahankan kelangsungan hidup.

Pada zaman modern sekarang ini memang sudah banyak sekali para ahli pendidikan yang membicarakan tentang bermain dan hubungannya dengan perkembangan anak, antara lain:

1. Teori Psikoanalis Sigmund Freud

2. Teori Kognitifa, Jean Piaget, Lev

Vygotsky, dst.

3. Teori Perkembangan sosial, dls.

Peran bermain dalam perkembangan sosial anak misalnya, menurut pandangan psikoanalisis adalah untuk mengatasi pengalaman traumatik dan keluar dari rasa frustasi. Tampaknya Freud melihatnya dalam pengalaman lahir. Dalam peristiwa kelahiran seorang bayi menyiratkan kesan tidak enak, trauma dan mungkin juga frustasi keluar dari rahim ibunya, sehingga anak akan merasa tenang dalam dekapan ibunya, dan bermain menyebabkan anak ceria dan menimbulkan kreatifitas.

Bagi Piaget, peran bermain terhadap perkembangan sosial anak adalah untuk memperaktikkan dan melakukan konsolidasi konsep-konsep serta keterampilan yang telah dipelajari sebelumnya. Menurut Vygotsky, bermain dapat memajukan berpikir abstrak dan dengan belajar ia akan dapat mengatur dirinya.

Dalam teori perkembangan sosial, seperti yang dikemukakan oleh Mildred Farten, menyatakan bahwa kegiatan bermain merupakan sarana sosialisasi. Dengan bermain kadar interaksi sosialnya akan meningkat. Kadar interaksi sosial tersebut dimulai dari bermain sendiri dan dilanjutkan dengan bermain secara bersama. Karena itu dalam konteks ini akan tampak, bahwa anak yang dibiasakan bermain akan lebih mudah menerima kehadiran orang lain dan berinteraksi dengan orang lain. Semakin banyak ia disosialisasikan dengan orang lain, maka akan semakin mudah ia berinteraksi dengan dan menerima (kehadiran) orang lain.

Dalam kontes agama Islam, setelah persalinan anak akan diadzankan oleh orang tuanya kemudian setelah tujuh hari ia akan diberi nama dan diakekahkan serta dipotong rambutnya di hadapan undangan yang diiringi 
dengan lagu-lagu pujian. Semua itu akan sangat menyenangkan bagi anak dan merupakan pengalaman interaksi sosial yang sangat baik dari proses sosialisasi.

\section{Makna Bermain}

Para ahli mendefinisikan bermain sebagai suatu perilaku yang mengandung motivasi internal yang berorientasi pada proses yang dipilih secara bebas dan bukan hanya prilaku pura-pura yang berorientasi pada suatu tujuan menyenangkan yang diperintahkan. Kegiatan bermain ini adalah fungsi dari seluruh manusia. Sandra J, Stone (1993). Karena itu, bermain dilakukan oleh siapa saja di berbagai belahan dunia, baik laki-laki maupun perempuan dari anak-anak sampai orang dewasa. Stone mengatakan bahwa bermain ada di setiap negara, budaya, bahasa, dimana saja anak-anak dunia bermain.

Menurut Karl Buhler dan Schenk Danziger, bermain adalah "kegiatan yang menimbulkan kenikmatan". Dan kenikmatan itu menjadi rangsangan bagi perilaku lainnya. Ketika anak-anak mulai mampu berbicara dan berfantasi, misalnya, fungsi kenikmatan meluas menjadi schaffensfreude (kenikmatan berkreasi). Konsep ini dikembangkan lebih lanjut oleh Charlotte Buhler yang menganggap bermain sebagai pemicu kreativitas. Menurutnya anak yang banyak bermain akan meningkatkan kreativitasnya.

Kendati bermain bukanlah bekerja dan tidak sungguh-sungguh, Sigmund Freud yakin bahwa anak-anak menganggap bermain sebagai sesuatu yang serius. Dalam bermain anak-anak menumpahkan seluruh perasaannya. Bahkan mampu "mengatur dunia dalamnya" agar sesuai dengan "dunia luar". Ia berusaha mengatur, menguasai, berpikir dan berencana. Karenanya menurut Erik Erikson, bermain berfungsi memelihara ego anak-anak. Hal ini dapat dipahami karena anak yang sedang bermain merasakan senang sehingga terpaksa ia harus mempertahankan kesenangannya itu atau sebaliknya ia akan memelihara egonya secara proporsional, sehingga menimbulkan rasionalitas dan tenggang rasa terhadap anak lainnya.
Semakin intens pengalaman itu dilalui anak akan semakin kuat juga interaksi sosialnya dalam proses sosialisasi tersebut.

Jean Piaget menyatakan, bahwa bermain menunjukkan dua realitas anak-anak, yaitu adaptasi terhadap apa yang sudah mereka ketahui dan respon mereka terhadap hal-hal baru. Dalam bermain, sarana sering menjadi tujuan. Banyak respon muncul, ya demi respon itu sendiri. Anak berlari, misalnya, bukan demi kesehatan tetetapi demi lari itu sendiri. Lari ya lari, titik. Jadi bagi anak, bermain adalah sarana untuk mengubah kekuatan potensial di dalam diri menjadi berbagai kemampuan dan kecakapan. Bermain juga bisa menjadi sarana penyaluran kelebihan energi dan relaksasi.

Sebagai implementasi olahraga melalui bermain yang dapat ditetapkan pada anak usia dini antara lain; Usia 2-3 tahun Olahraga yang sifatnya belum terstruktur, seperti berlari, berayun-ayun, memanjat, dan bermain air. Pada usia 2 tahun, anak sudah mampu melompat dengan satu atau kedua kaki, dan berlari (di usia ahun sudah bisa divariasikan arahnya kanan-kiri dan lain sebagainya).Usia 4-5tahun, Biasanya, anak sudah bisa menggelindingkan bola besar, menangkap bola, serta piawai dengan sepeda roda tiga. Ia juga mulai suka berenang atau bersenam (tetapi tanpa diprogram).

\section{PENUTUP \\ Simpulan}

Pendidikan karakter merupakan upaya-upaya yang dirancang dan dilaksanakan secara sistematis untuk menanamkan nilainilai perilaku peserta didik yang berhubungan dengan Tuhan Yang Maha Esa, diri sendiri, sesama manusia, lingkungan, dan kebangsaan yang terwujud dalam pikiran, sikap, perasaan, perkataan, dan perbuatan berdasarkan norma-norma agama, hukum, tata krama, budaya, dan adat istiadat.

Pendidikan Jasmani Olahraga dan Kesehatan (penjasor) pada hakikatnya adalah proses pendidikan yang memanfaatkan aktivitas fisik untuk menghasilkan perubahan holistik dalam kualitas individu, baik dalam hal fisik, mental, serta emosional. Pendidikan 
jasmani memperlakukan anak sebagai sebuah kesatuan utuh, mahluk total, daripada hanya menganggapnya sebagai seseorang yang terpisah kualitas fisik dan mentalnya.

Melalui proses pembelajaran Penjasor meruapakan media yang dipandang sangat tepat dan ampuh dalam pemebntukan sistem nilai dan karakter. Itu aka terwujud bila diberikan rangsangan sedini mungkin sesuai dengan hukum perkembangan anak. Oleh karena itu metode bermain dan permainan sangat baik dilakukan bagi anak usia dini dengan mengedepankan keutuhan gerak anak dan menampilakan keteladanan yang baik dari para instruktur dan pendidik.

\section{DAFTAR PUSTAKA}

Alim, S. (2011). Pengembangan Nilai-nilai Etika Inti dalam Pendidikan Karakter. Dalam http://blog.elearning. unesa.ac.id/alim-sumarno/. (diunduh 05 Mei 2012)

Depdiknas. (2007). Kerangka DasarKurikulum Pendidikan Anak Usia Dini. Jakarta: Pusat Kurikulum Direktorat Pendidikan Anak Usia Dini. Direktorat Pembinaan TK dan SDUniversitas Negeri Jakarta Tim Pengembang: dalam http://hidayatsoeryana word press. com/2008/05/05/kerangka-dasar kurikulum-paud-lengkap/ (diunduh pa-da 23 November 2011).

Fidesrinur. (2010). Pemerataan Dan Perluasan Akses Layanan Paud Suatu Alternatif Solusi Komprehensif Terhadap Pelayanan Pendidikan Anak Usia Dini (PAUD) Di Indonesia. Makalah Rembuk Nasioanl Pendidikan 2011.
Farihen, H. (2011). Konsep Bermain Bagi Anak Usia Dini. Dalam Farihenhttp://www. fai.umj.ac.id/: diunduh pada tanggal 24 Desember 2011

Kemdiknas. (2011). Pedoman Pelaksanaan Pendidikan Karakter [Berdasarkan Pengalaman di Satuan Pendidikan Rintisan] Jakarta: Badan Penelitian dan Pengembangan, Pusat Kurikulum dan Perbukuan. hal 4.

Arief, M. (2008). Olahraga Untuk Usia 2-6 Tahun. Dalam http://ariefboy. Multiply.com/reviews/ item/ 4?\&show _interstitial $=1 \& \mathrm{u}=\% 2$ Freviews $\% 2$ Fitem (diunduh 05 Mei 2012)

Nana, P. (2011). Membangun Karakter Anak Usia Dini dalam eBulletin dirjen PAUDNI no 21. dalam http:// www.paud.kemdiknas.go.id/ diunduh tanggal 05 mei 2012)

Puspita, F. (2011). Pendidikan Karakter Bagi Anak Usia Dini. Dalam Jurnal Pendidikan Non Formal. Edisi 8 tahun 2011. hal $131-144$.

Rencana Strategis Kementrian Pendidikan Nasional (Renstra Dikans) 2010 2014.

Undang-undang No 20 tahun 2003 tentang sistem Pendidikan Nasional. Pasal 28

Widya, A. P. (2010). Pendidik Pendidikan Anak Usia Dini (Paud) sebagai Model Perilaku Anak Usia Dini: dalam http: //www.bppnfi-reg4. net. diunduh pada tanggal 27 De-sember 2011. 